\title{
PENERAPAN TEKNOLOGI BUDIDAYA JENUH AIR UNTUK MENINGKATKAN PENDATAPATAN PETANI KEDELAI HITAM \\ DI KABUPATEN TANJUNG JABUNG TIMUR
}

Implementation of Water Saturated Farming Technology to Incease Black Soybean

Farmers' Income in Tanjung Jabung Regency

\author{
Weni Lestari \\ Badan Penelitian dan Pengembangan Daerah Provinsi Jambi \\ JI. R.M. Nur Atmadibrata No. 01 A Telanaipura Jambi, \\ Email: wenilestarisp@gmail.com
}

\begin{abstract}
The study was conducted to determine how much farmer's income from black soybean farming in Tanjung Jabung Timur Regency. The study conducted from July 2017 until November 2017 in the 3 districts, that are Berbak, Dendang and Rantau Rasau. The retrieved data are primary and secondary data. Primary data were obtained from 86 respondents which are taken directly appoint (purposive sampling) and secondary data obtained from the Goverment Institutions and publications. Income is calculated using the revenue analysis. This analysis can also determine the level of farming efficiency whis is calculated by dividing the revenues and costs. Advantage of soybean farming with BJA technology compared to conventional farming is production by $B J A$ technology is bigger than conventional and BJA technology is suitable to apply in suboptimal land. The results show that farmer's income with BJA technology is bigger than conventional, but on economic aspect input costs added $(68,1 \%)$ were not balance with increasing production (57,6\%). The percentage of input costs added that over than the percentage of revenues it proves that the soybean farming with BJA technology is not efficient. This research also shows that soybean farming in this regency is profitable for farmers, which is $R / C$ ratio $>1$.
\end{abstract}

Keywords : Soybean, Income, Water Saturated Cultivation Technology

\begin{abstract}
Abstrak
Penelitian ini bertujuan untuk mengetahui seberapa besar perubahan pendapatan petani kedelai hitam dengan penerapan teknologi Budidaya Jenuh Air di Kabupaten Tanjung Jabung Timur. Penelitian ini dilaksanakan pada bulan Juli hingga Oktober 2017.di tiga kecamatan yaitu Kecamatan Berbak, Dendang dan Rantau Rasau. Data yang digunakan adalah data primer dan data sekunder.Data primer diperoleh dari 86 responden yang diambil secara purposive sementara data sekunder diperoleh dari instansi terkait dan beberapa publikasi yang relevan dengan penelitian. Pendapatan dihitung dengan analisis pendapatan yang juga dapat melihat tingkat efisiensi yang dihitung dengan membandingkan penerimaan yang diterima petani dengan biaya yang dikeluarkan. Kelebihan teknologi budidaya jenuh air adalah produksi kedelai hitam yang dihasilkan lebih tinggi dibandingkan dengan produksi dari usahatani konvensional dan teknologi ini sesuai untuk diterapkan di lahan sub optimal seperti lahan pasang surut. Hasil penelitian menunjukkan bahwa Pendapatan petani kedelai hitam yang menerapkan teknologi BJA Rp. 2.140.000 lebih tinggi dari pendapatan yang diperoleh dari usahatani konvensional Rp1.810.000. Nilai R/C-Ratio pada budidaya BJA $(1,2)$ lebih kecil dibanding nilai R/C-Ratio pada budidaya kedelai konvensional $(1,3)$.
\end{abstract}

Kata Kunci: Kedelai, Pendapatan, Teknologi budidaya Jenuh air

\section{PENDAHULUAN}

Kedelai (Glicine max) merupakan komoditas tanaman pangan yang sangat dibutuhkan dan dipandang penting karena merupakan sumber protein nabati, lemak, vitamin dan mineral yang murah 
dan mudah tumbuh di berbagai wilayah Indonesia. Hasil olahan produk berbahan baku kedelai yang sudah melekat dengan masyarakat seperti susu kedelai, tahu, kembang tahu, kecap, oncom, tauco, tempe, minyak makan dan tepung kedelai. Selain itu, juga banyak dimanfaatkan sebagai bahan pakan ternak (Adisarwanto, 2005).

Provinsi Jambi termasuk salah satu daerah potensial untuk pengembangan usahatani kedelai walaupun produktivitas kedelai di Provinsi Jambi masih lebih rendah dari produktivitas rata-rata nasional, yakni 1,37 ton/ha (Badan Pusat Statistik Provinsi Jambi, 2016). Pengembangan usahatani kedelai di Provinsi Jambi masih memungkinkan untuk meningkatkan produktivitas melalui intensifikasi maupun ekstensifikasi masih cukup tersedia dengan menerapkan inovasiinovasi teknik budidaya kedelai.

Dalam berusahatani, petani mengupayakan agar hal yang diperoleh secara ekonomis atau menguntungkan, dimana biaya yang dikeluarkan dapat menghasilkan produksi maksimal yang pada akhirnya pendapatan petani akan meningkat, dan dengan meningkatnya pendapatan maka secara otomatis tingkat kesejahteraan petani tersebut akan meningkat. Soekartawi (2002), bahwa tujuan berusahatani dikategori- kan menjadi dua yaitu memaksimumkan keuntungan atau meminimumkan biaya.Konsep maksimisasi keuntungan adalah bagaimana mengalokasikan sumber-daya dengan jumlah tertentu seefisien mungkin untuk memperoleh keuntungan maksi-mum.Sedangkan konsep minimisasi biaya adalah bagaimana menekan biaya produksi sekecil-kecilnya untuk mencapai tingkat produksi tertentu.

Program pengembangan usahatani kedelai telah dilaksanakan di Kabupaten Tanjung Jabung Timur. Upaya pengembangan kedelai ini dimulai sejak tahun 2010 melalui program ekstensifikasi dan intensifikasi.

Tujuan pengembangan usahatani kedelai di daerah ini, selain merupakan bagian dari program nasional dalam mewujudkan swasembada kedelai, juga sebagai upaya dalam meningkatkan taraf ekonomi petani khususnya dan masyarakat pedesaan umumnya.

Perkembangan produksi kedelai di Kabupaten Tanjung Jabung Timur kurang begitu menggembirakan. Pada tahun 2010, luas tanam sebesar $1.625 \mathrm{Ha}$ dan produksi sebesar 1.889 ton. Namun pada tahun 2015, keadaan luas tanam dan produksi menurun secara drastis, yakni berturut-turut sebesar 736 hadan 1.028 ton dengan produktivitas rata-rata yang dicapai baru sekitar 1,35 ton/ha (Badan Pusat Statistik Provinsi Jambi, 2016). 
Capaian inimasih di bawah ratarata produktivitas kedelai nasional maupun rata-rata produktivitas Provinsi Jambi.Program pengembangan usahatani kedelai di Kabupaten Tanjung Jabung Timur tidak akan berkelanjutan tanpa adanya perbaikan produktivitas.

Salah satu terobosan baru yang diperkenalkan kepada petani untuk meningkatkan produksi kedelai yaitu teknologi budidaya jenuh air (BJA). Teknologi budidaya jenuh air sangat sesuai dikembangkan pada lahan pasang surut yang masih potensial ketersediaannya di Kabupaten Tanjung Jabung Timur. Perbedaannya dengan teknik budidaya kedelai konvensional terletak pada tata kelola air pasang yang terdapat pada lahan. Penerapan teknik budidaya jenuh air pada usahatani kedelai seluas 400 ha yang tersebar di Kecamatan Berbak (100 Ha), Rantau Rasau $(140 \mathrm{Ha})$ dan Dendang $(160 \mathrm{Ha})$.

$$
\text { Bertitik tolak dari tujuan }
$$
berusahatani sebagaimana diuraikan di atas Kabupaten Tanjung Jabung Timur sebagai sentra pengembangan agribisnis kedelai di Provinsi Jambi dengan memanfaatkan lahan-lahan sub-optimal yang tersedia dalam rangka meningkatkan pendapatan dan tingkat kesejahteraan petani kedelai.

\section{Rumusan Masalah}

Berdasarkan latar belakang yang dikemukakan diatas, maka yang men- jadi permasalahan dalam penelitian ini adalah berapa besar pendapatan dari usahatani kedelai hitam di Kecamatan Berbak Kabupaten Tanjung Jabung Timur

\section{Tujuan dan Manfaat Penelitian}

Peneltian ini bertujuan untuk mengetahui pendapatan petani dari usahatani kedelai hitam di Kabupaten Tanjung Jabung Timur. Adapun manfaat dari penelitian ini adalah sebagai bahan informasi bagi petani agar dapat mengembangkan usahatani kedelai hitam dan penelitian ini diharapkan akan menjadi bahan pertimbangan untuk penelitian selanjutnya.

\section{TINJAUAN PUSTAKA}

\section{Konsep Usahatani}

Soekartawi (1995), usahatani adalah ilmu yang mempelajari bagaimana seseorang mengalokasikan sumberdaya yang ada secara efektif dan efisien dengan tujuan untuk memperoleh keuntungan yang tinggi pada waktu tertentu. Dikatakan efektif bila petani atau produsen dapat mengalokasikan sumber daya yang mereka miliki atau yang dikuasai sebaik-baiknya dan dikatakan efisien bila pemanfaatan sumberdaya tersebut menghasilkan keluaran (output) yang melebihi masukan (input).

Hernanto (1993) menyatakan unsurunsur pokok usahatani yang dikenal dengan faktor-faktor usahatani dikenal 
dengan faktor-faktor produksi antara lain: tanah,tenaga kerja, modal dan manajemen

Konsep Biaya, Penerimaan dan Pendapatan

Dalam usahatani tentunya para petani memperhitungkan biaya-biaya yang dikeluarkan serta memperhitungkan penerimaan yang diperoleh. Pembiayaan merupakan salah satu aspek paling menentukan dalam pengembangan usaha. Pembiayaan agribisnis dapat diperoleh dari modal sendiri atau meminjam dari beberapa sumber keuangan, seperti pemodal perorangan, lembaga keuangan dan bank (Krisnamurthi, 2001).

Biaya atau pengeluaran total usahatani adalah semua nilai masukan yang habis dipakai atau dikeluarkan dalam produksi, tetapi tidak termasuk tenaga kerja keluarga petani. Biaya (Cost) merupakan pengeluaran atau pengorbanan yang dapat menimbulkan pegurangan terhadap manfaat yang kita terima (Kasmir dan Jakfar, 2007). Ditambahkan lagi oleh Soekartawi (1995), biaya usahatani terdiri dari biaya tetap dan biaya tidak tetap.

Rahim dan Hastuti (2008), penerimaan usahatani adalah perkalian antara produksi yang diperoleh dengan harga jual. Pernyataan tersebut dapat dinyatakan dalam rumus sebagai berikut:

$$
\mathrm{TR}=\mathrm{Y} \times \mathbf{P y}
$$

Dimana :

$\mathrm{TR}=$ Total Revenue/ Penerimaan (Rp)

$Y=$ Produksi yang diperoleh dalam suatu usaha tani $(\mathrm{Kg})$

Py = Harga Jual $Y(R p)$

Berusahatani sebagai suatu kegiatan untuk memperoleh produksi di lahan pertanian, pada akhirnya akan dinilai dari biaya yang dikeluarkan dan penerimaan yang diperoleh. Selisih antara penerimaan tunai usahatani dan pengeluaran tunai usahatani disebut pendapatan tunai usahatani.

$$
\pi=\mathbf{T R}-\mathbf{T C}
$$

Dimana :

I = Pendapatan (Income)

TR = Total Revenue (Penerimaan)

$\mathrm{TC}=$ Total Cost (Total Biaya)

Untuk meningkatkan pendapatan, maka petani harus berusaha meningkatkan hasil-hasil produksi agar memperoleh peningkatan pendapatan dengan memaksimalkan input-input faktor yang mempengaruhi (Soekartawi, 1995). Pendapatan rumah tangga petani bersumber dari dalam usahatani dan pendapatan dari luar usahatani. Pendapatan dari dalam usahatani meliputi pendapatan dari tanaman yang diusahakan oleh petani. Sedangkan dari luar usahatani bersumber dari pendapatan selain usahatani yang diusahakan.

Deskripsi Teknologi Budidaya Jenuh Air 
Penerapan inovasi teknologi budidaya jenuh air di lahan pasang surut, produktivitas kedelai meningkat sekitar 8 ku/ha, atau mencapai produktivitas ratarata sebesar 2 ton/ha (Direktorat Jenderal Tanaman Pangan, 2015). Hasil ini jauh lebih tinggi dibanding produktivitas kedelai yang dicapai dengan teknik budidaya konvensional yang diterapkan petani selama ini, yakni di bawah 1,5 ton/ha. Dengan demikian, teknik budidaya kedelai jenuh air pada lahan pasang surut merupakan salah satu solusi kendala ekstensifikasi usahatani pada lahan-lahan subur.

Sistem pengelolaan usahatani kedelai dengan teknik budidaya jenuh air pada lahan pasang surut adalah penanaman kedelai dengan memberikan irigasi terus-menerus sejak tanam sampai panen dan mengatur tinggi permukaan air tetap, sehingga lapisan di bawah perakaran jenuh dengan air. Metodenya adalah meninggikan permukaan tanah sekitar $30 \mathrm{~cm}$ dalam bentuk barisan memanjang untuk tempat pertanaman kedelai. Di antara barisan tanaman kedelai tersebut dibiarkan tergenang oleh air pasang. Agar pertumbuhan tanaman kedelai pada lahan pasang surut ini lebih baik, ditambahkan amelioran (kapur pertanian) dan rhizobium selain pemupukan NPK dan tindakan budidaya lainnya (Direktorat Jenderal Tanaman Pangan,
2015). Sedangkan pada budidaya kedelai secara konvensional, air pasang yang terdapat di lahan dialirkan hingga kering.

\section{METODOLOGI PENELITIAN}

Penelitian ini dilakukan secara purposive sampling (sengaja) di Kabupaten Tanjung Jabung Timur, Provinsi Jambi. Lokasi penelitian difokuskan pada kecamatan sentra produksi kedelai yang paling menonjol yakni Kecamatan Berbak, Rantau Rasau dan Dendang. Pelaksanaan pertanaman dilaksanakan bulan Juli 2017 dan panen pada bulan Oktober - Nopember 2017. Data yang dikumpulkan terdiri dari data primer dan data sekunder. Data primer diperoleh melalui wawancara langsung dengan menggunakan daftar pertanyaan yang telah disiapkan dalam bentuk kuesioner, sedangkan data sekunder diperoleh dari instansi-instansi yang terkait dalam penelitian ini.

\section{Metode Penarikan Sampel}

Pada ketiga kecamatan tersebut, Petani yang menerapkan teknologi budidaya jenuh air sebanyak 370 orang. Penentuan jumlah sampel dari setiap kecamatan sentra produksi tempat penelitian ditentukan secara proporsional dengan menggunakan persamaan sebagai berikut:




Jumlah petani kedelai yang dijadikan sebagai sampel dalam penelitian ini adalah:berjumlah 86 orang yang terdiri dari 38 orang petani di Kecamatan Berbak, 28 orang petani di Kecamatan Rantau Rasau dan 20 orang petani di Kecamatan Dendang.

\section{Analisis Data}

Analisis data yang digunakan dalam penelitian ini adalah analisis secara deskriptif dan disajikan dalam bentuk tabel. Untuk menganalisis pendapatan usahatani kedelai hitam dalam perolehan pendapatan, menggunakan rumus:

$$
\begin{aligned}
& \pi=\mathrm{TR}-\mathrm{TC} \\
& \mathrm{TR}=\mathrm{Y} . \mathrm{Py} \\
& \mathrm{TC}=\mathrm{FC}+\mathrm{VC}
\end{aligned}
$$

Untuk mengetahui kelayakan usahatani kedelai hitam di daerah penelitian menggunakan pendekatan matematik sebagai berikut.

$\mathrm{R} / \mathrm{C}=\mathrm{TR} / \mathrm{TC}$
Di mana :

$\mathrm{R} / \mathrm{C}=$ Revenue and Cost Ratio, $\mathrm{TR}=$ Penerimaan kotor rata-rata $(\mathrm{Rp})$, $\mathrm{TC}=$ Biaya total rata-rata $(\mathrm{Rp})$.

Jika $\mathrm{R} / \mathrm{C}>1$, maka usahatani dianggap layak, dan jika $\mathrm{R} / \mathrm{C}<1$ dianggap tidak layak.

\section{HASIL DAN PEMBAHASAN}

Kabupaten Tanjung Jabung Timur memiliki luas wilayah $5.445 \mathrm{~km}^{2}$ atau 10,2\% dari luas wilayah Provinsi Jambi. Kecamatan yang dijadikan lokasi penelitian yaitu kecamatan Dendang dengan luas wilayah $478,17 \mathrm{Km}^{2}(8,78 \%)$ , kecamatan Rantau Rasau luas wilayah $356,12 \mathrm{Km}^{2}$ (6,54 \%) dan kecamatan Berbak luas 194,46 Km²(3,57\%).

\section{Identitas Petani Sampel}

Adapun identitas yang dimaksud adalah umur petani, jumlah anggota keluarga aktif,tingkat pendidikan ,pengalaman bertani kedelai dan luas lahan akan disajikan pada Tabel 1

Tabel 1. Identitas Petani Responden di Daerah Penelitian

\begin{tabular}{|l|l|r|r|}
\hline Identitas Responden & Uraian & Frekuensi & Persentase (\%) \\
\hline Umur Petani (Tahun) & $<30$ tahun & 9 & 10,47 \\
& $30-40$ tahun & 18 & 20,93 \\
& $40-50$ tahun & 34 & 39,53 \\
& $50-60$ tahun & 23 & 26,74 \\
& $>60$ tahun & 2 & 2,32 \\
\hline Jumlah Anggota Keluarga & 2 orang & 12 & 13,95 \\
& 3 orang & 58 & 67,44 \\
& 4 orang & 11 & 12,79 \\
& 5 orang & 5 & 5,88 \\
\hline Tingkat Pendidikan & SD & 47 & 59,65 \\
& SMP & 13 & 15,12 \\
& SMA & 17 & 19,77 \\
& Tidak Sekolah & 9 & 10,47 \\
\hline Pengalaman Berusahatani i & $<5$ tahun & 17 & 19,77 \\
(Tahun) & $6-10$ tahun & 24 & 27,91 \\
& $11-15$ tahun & 43 & 50,00 \\
\hline
\end{tabular}

154| Khazanah Intelektual Volume 2 Nomor 2 Tahun 2018 


\begin{tabular}{|l|l|r|r|}
\hline & $>15$ tahun & 2 & 2,33 \\
\hline Luas Lahan $(\mathrm{Ha})$ & $1 \mathrm{Ha}$ & 51 & 59,30 \\
& $1,5 \mathrm{Ha}$ & 11 & 12,80 \\
& $2 \mathrm{Ha}$ & 24 & 27,91 \\
\hline
\end{tabular}

Sumber : Data Primer, 2018

Tabel 1 dapat diketahui dari 86 orang petani sampel umur yang dominan untuk usahatani kedelai adalah pada kisaran umur 41 - 50 tahun tahun, yang merupakan usia produktif, dimana pada usia tersebut sesorang dapat dikatakan memiliki kemampuan fisik yang baik dan produktif dalam mengelola usaha taninya. Pada usia itu pula petani memiliki kematangan sikap dan pemikiran untuk memtuskan hal- hal yang berkaitan dengan usaha taninya.

Jumlah anggota keluarga petani yang aktif dalam usahatani kedelai yang mendominasi adalah 2 - 3 orang, biasanya suami dan istri dan ditambah satu atau dua orang anak. Karena kekurangan tenaga kerja, umumnya petani membayar tenaga kerja dari luar keluarga, terutama pada saat kegiatan pengolahan tanah dan musim panen tiba.

Tabel 1 juga menunjukkan bahwa lebih dari $50 \%$ petani sampel didaerah penelitian hanya lulusan Sekolah Dasar (SD). Hal ini menunjukkan bahwa tingkat pendidikan formal para petani di daerah penelitian masih tergolong rendah. Salah satu langkah yang harus dilakukan adalah melalui pendidikan non formal seperti penyuluhan dan pembentukan kelompok tani. Di daerah penelitian, petani memperoleh pendidikan penyuluhan dan pembentukan kelompok tani, aktifnya peran pendidikan non formal menyebabkan petani dapat menerima inovasi baru yang diberikan pemerintah melalui sosialisasi kepada petani.

Pendidikan formal petani paling tinggi hanya setingkat SD, meski demikian petani sudah sangat berpengalaman karena dapat dilihat $50 \%$ petani menekuni budidaya kedelai lebih dari 11 Tahun. Pengalaman bertani yang sedemikian lama tersebut merupakan modal pengetahuan yang memungkinkan petani untuk mengelola usahatani kedelai secara baik.Luas lahan yang dimiliki oleh petani sampel sebagian besar seluas 1 hektar, ada sekitar 59,30\%, dengan rata-rata kepemilikan lahan 1,34 Ha per-pertani.

\section{Gambaran Penerapan Teknologi BJA di Kabupaten Tanjung Jabung Timur}

Pemerintah memperkenalkan teknik BJA kepada petani melalui program berbantuan yang mana petani yang berminat mencoba diberi bantuan sarana produksi berupa benih, pupuk NPK, Pestisida, rhizobium dan kapur pertanian (kaptan). Jika dibandingkan dengan teknik konvensional, petani tidak menggunakan 
kapur pertanian dan rhizobium pada lahan usahatani kedelai. Benih kedelai yang digunakan petani juga berasal dari hasil panen kedelai sebelumnya yang kualitasnya tentu lebih rendah dibanding benih kedelai bantuan pemerintah.
Adanya perbedaan jumlah input dan persiapan tanam antara teknik BJA dan teknik konvensional, serta merta juga menyebabkan perbedaan alokasi tenaga kerja dalam kegiatan usahatani kedelai. Untuk lebih jelasnya disajikan pada Tabel2.

Tabel 2. Perbandingan Input Usahatani Kedelai Teknik BJA dan Konvensional untuk Luas Lahan Garapan Satu Hektar.

\begin{tabular}{lrrr}
\hline \multicolumn{1}{c}{ Jenis Input } & Teknik BJA & Konvensional & Perbedaan \\
\hline Tenaga Kerja (HK) & 61 & 42 & 19 \\
Kapur Pertanian (Kg) & 200 & - & 200 \\
Rhizobium (gr) & 100 & - & 100 \\
Pupuk NPK (Kg) & 400 & 300 & 100 \\
Pestisida (Ltr) & 7 & 4,8 & 2,2 \\
Benih Kedelai (Kg) & 40 & 40 & -
\end{tabular}

Tabel 2 terlihat perbedaan curahan hari kerja $(\mathrm{HK})$ antara teknik BJA dan konvensional adalah sebanyak 19 HK. Perbedaan ini terjadi karena adanya perbedaan pada sistem budidaya kedelai, yang mana pada lahan gambut pasang surut, air selalu tergenang sepanjang musim tanam kedelai. Pada teknik BJA membutuhkan tambahan hari kerja yang diperuntukkan untuk pembuatan parit-parit drainase di dalam areal pertanaman.

Persoalan bagi petani tentang ketersediaan tenaga kerja yang dibutuhkan dalam pengerjaan usahatani kedelai. Hal ini karena tenaga kerja dari dalam keluarga yang aktif membantu sangat terbatas, yakni $2-3$ orang saja. Oleh karena itu terpaksa mendatangkan tenaga kerja upahan yang berasal dari luar keluarga. Pada umumnya tenaga kerja dari luar keluarga yang bersedia bekerja pada usahatani kedelai hanyalah tenaga kerja wanita yang produktivitasnya lebih rendah dibanding tenaga kerja pria dengan upah $1 \mathrm{HK}$ sebesar Rp. 50.000.

Perbedaan penggunaan input lainnya antara budidaya kedelai yang menerapkan teknik BJA dengan teknik konvensional adalah benih yang digunakan petani. Meskipun jumlah kebutuhan benih kedelai untuk setiap hektarnya sama, namun benih kedelai yang digunakan pada budidaya kedelai teknik BJA adalah benih bersertifikat yang diperoleh dari badan/balai yang berwenang memperbanyak benih. 
Sedangkan benih yang digunakan oleh petani yang menerapkan teknik budidaya konvensional berasal dari benih hasil panen sebelumnya dengan kualitas lebih rendah dan harganya lebih murah.

\section{Biaya Produksi}

Budidaya kedelai dengan penerapan teknik BJA jauh lebih intensif dibanding teknik budidaya kedelai konvensional. Biaya yang dipergunakan dalam usahatani kedelai teknik BJA adalah lebih besar dibandingkan dengan biaya yang dikeluarkan pada usahatani kedelai teknik konvensional, perbedaan terletak dari penggunaan tenaga kerja dan sarana produksi lainnya seperti pemakaian Kapur, Rhizobium, pupuk, dsb.Perbedaan korbanan biaya yang lebih besar pada teknik budidaya BJA dibanding teknik konvensional sebagai-mana disajikan pada Tabel 3.

Tabel 3.Besaran Biaya Input Budidaya Kedelai Teknik BJA dan Konvensional

\begin{tabular}{clccc}
\hline $\begin{array}{c}\text { Teknik } \\
\text { Budidaya }\end{array}$ & \multicolumn{1}{c}{ Jenis Input } & Jumlah & $\begin{array}{c}\text { Harga Satuan } \\
(\mathrm{Rp})\end{array}$ & $\begin{array}{c}\text { Biaya } \\
(\mathrm{Rp})\end{array}$ \\
\hline \multirow{5}{*}{ Konvensional } & Tenaga Kerja (HK) & 42 & 50.000 & 2.100 .000 \\
& Kapur Pertanian (Kg) & - & - & - \\
& Rhizobium (g) & - & - & - \\
& Pupuk NPK (Kg) & 300 & 12.000 & 3.600 .000 \\
& Pestisida (liter) & 4,8 & 90.000 & 430.000 \\
& Benih Kedelai (Kg) & 40 & 16.000 & 640.000 \\
\hline Total & & & 6.770 .000 \\
\hline \multirow{3}{*}{ BJA } & Tenaga Kerja (HK) & 61 & 50.000 & 3.050 .000 \\
& Kapur Pertanian (Kg) & 200 & 6.000 & 1.200 .000 \\
& Rhizobium (g) & 100 & 6.000 & 600.000 \\
& Pupuk NPK (Kg) & 400 & 12.000 & 4.800 .000 \\
& Pestisida (liter) & 7 & 90.000 & 630.000 \\
& Benih Kedelai (Kg) & 40 & 20.000 & 800.000 \\
\hline Total & & & 11.380 .000 \\
\hline Selisih Biaya Input & Antara BJA dengan Konvensional & & 4.610 .000 \\
& & & & $68,1 \%)$ \\
\hline
\end{tabular}

Selanjutnya biaya input dibayar setahun sekali. Demikian pula usahatani sebagaimana dicantumkan pembelian alat-alat untuk kegiatan dalam Tabel 3 dapat dikelompokkan usahatani kedelai, nilainya juga relatif kecil menjadi dua yakni upah tenaga kerja karena pembeliannya hanya empat tahun dan pembelian sarana produksi. Biaya sekali. Begitupun untuk biaya sewa lahan, tersebut termasuk dalam kelompok tidak ada karena lahan yang digarap biaya tidak tetap. Sedangkan biaya tetap tidak dimasukkan petani sebagai biaya input karena jumlahnya relatif petani adalah lahan hak milik. Untuk selengkapnya pengelompokan biaya input usahatani kedelai di lokasi penelitian kecil, misalnya pajak yang hanya disajikan pada Tabel 4. 
Tabel 4. Pengelompokan Biaya Input Usahatani pada Budidaya Konvensional dan BJA

\begin{tabular}{lrrrr} 
Input Usahatani & Konvensional & BJA & Beda & $\%$ \\
\hline Upah Tenaga Kerja (Rp) & 2.100 .000 & 3.050 .000 & 950.000 & 45,2 \\
Sarana Produki (Rp) & 4.670 .000 & 8.330 .000 & 3.660 .000 & 78,4 \\
\hline Total (Rp) & 6.770 .000 & 11.380 .000 & 4.610 .000 & \\
\hline
\end{tabular}

Bila dilihat selisih biaya input persoalan bila petani akan menerapkan usahatani kedelai yang menerapkan paket teknologi BJA secara swadaya. budidaya konvensional dengan teknik Modal menjadi masalah utama bagi petani BJA adalah mencapai rata-rata $\mathrm{Rp}$. karena korbanan biaya input yang lebih 4.610.000 tiap hektarnya atau dengan besar belum tentu seimbang dengan perbedaan sekitar 68,1\%. Bagi petani pendapatan yang akan diterima kelak. kedelai, tambahan input biaya sebesar Rp. 4.610.000 bukan hal gampang meskipun sekiranya dengan tambahan biaya tersebut dapat memberikan hail panen yang lebih besar.

Akan tetapi tetapmenimbulkan

Pendapatan

Untuk melihat pendapatan yang diterima petani kedelai akan dihitung dengan cara penerimaan usahatani dikurangi dengan biaya input yang akan disajikan pada Tabel 5.

Tabel 5. Biaya Input, Hasil Panen, Penerimaan dan Pendapatan Petani Kedelai Pada Dua Teknik Budidaya Kedelai yang Berbeda

\begin{tabular}{lcccc}
\hline $\begin{array}{c}\text { Teknik } \\
\text { Budidaya }\end{array}$ & $\begin{array}{c}\text { Biaya Input } \\
(\mathbf{R p})\end{array}$ & $\begin{array}{c}\text { Panen } \\
(\mathbf{k g})\end{array}$ & $\begin{array}{c}\text { Penerimaan } \\
\mathbf{( R p )}\end{array}$ & $\begin{array}{c}\text { Pendapatan } \\
\mathbf{( R p )}\end{array}$ \\
\hline Konvensional & 6.770 .000 & 1.320 & 8.580 .000 & 1.810 .000 \\
BJA & 11.380 .000 & 2.080 & 13.520 .000 & 2.140 .000 \\
Peningkatan & 4.610 .000 & 760 & 4.940 .000 & 330.000 \\
\hline Persentase & $\mathbf{6 8 , 1}$ & $\mathbf{5 7 , 6}$ & $\mathbf{5 7 , 6}$ & $\mathbf{1 8 , 2}$ \\
(\%) & & & & \\
\hline
\end{tabular}

Catatan: Harga jual kedelai adalah Rp. 6.500/kg

Dari Tabel 5 terlihat bahwa 603.300,00/bulan. Sedangkan petani pendapatan yang diperoleh dari menerapkan budidaya kedelai dengan berusahatani kedelai dengan teknik BJA diperoleh pendapatan sebesar menerapkan teknik konvensional adalah sebesar Rp1.810.000 untuk satu kali Rp. 2.140.000 untuk satu kali musim tanam atau Rp. 713.300,00/bulan. Dalam musim tanam yang berlangsung selama hal ini, kenaikan pendapatan petani jika 3 bulan atau sebesar Rp menerapkan teknik BJA dalam usahatani 
kedelai hanya sebesar Rp. 330.000 untuk satu kali musim tanam.

Pada Tabel 5 diatas juga terlihat bahwa penerapan paket teknologi BJA memang mampu dan tepat untuk diterapkan dalam mewujudkan swasembada kedelai meningkatkan hasil panen sebesar $760 \mathrm{~kg} / \mathrm{ha}$, sehingga perlu diperkenalkan kepada petani karena hasil panen yang dicapai cukup signifikan peningkatannya. Hasil panen yang tinggi belum tentu akan memberikan pendapatan yang tinggi pula karena dari sisi ekonomis ada tambahan biaya input usahatani sebesar Rp 4.610.000 atau sekitar $68,1 \%$, dan perolehan tambahan pendapatan hanya sebesar Rp. 330.000. Bagi petani kedelai tentu tambahan sebesar Rp. 330.000 tidak seimbang dengan korbanan tambahan sebesar Rp. 4.610 .000 atau $18,2 \%$

\section{Analisis Kelayakan Usahatani Kedelai}

Analisis kelayakan usahatani kedelai dalam penelitian ini didasarkan pada perhitungan rasio $(R / C)$ antara rata-rata penerimaan total usahatani (TR) terhadap rata-rata total biaya produksi (TC) yang dikorbankan untuk kegiatan proses produksi dalam usahatani. Suatu usaha-tani dikatakan layak jika nilai Nilai $R / C$-Ratio> 1 dan berikut hasil perhitungan rasio $(R / C)$ dapat dilihat pada Tabel 6 .

\section{Tabel 6. Kelayakan Usahatani Kedelai}

\begin{tabular}{lccrc}
\hline $\begin{array}{l}\text { Teknik } \\
\text { Budidaya }\end{array}$ & $\begin{array}{c}\text { Total Revenue } \\
(\text { TR })\end{array}$ & Total Cost (TC) & R/C-Ratio & B/C-Ratio \\
\hline Konvensional & Rp. 8.580 .000 & Rp. 6.770 .000 & 1,3 & 0,27 \\
BJA & Rp. 13.520 .000 & Rp. 11.380 .000 & 1,2 & 0,19
\end{tabular}

Dari Tabel 6 terlihat bahwa usahatani kedelai dengan teknik budidaya secara konvensional diperoleh nilai R/C-Ratio sebesar 1,3 sementara usahatani kedelai yang menerapkan teknik BJA diperoleh nilai R/C-Ratio sebesar 1,2. Berdasarkan nilai R/CRatio tersebut, baik usahatani kedelai yang dikelola secara konvensional maupun yang menerapkan paket teknologi BJA layak diusahakan karena nilai R/C-Ratio lebih besar dari 1. Tetapi jika dibandingkan nilai R/C-Ratio pada usahatani kedelai konvensional lebih tinggi daripada usahatani kedelai dengan teknik BJA. Hal ini berarti biaya input pada teknik BJA lebih besar dibandingkan biaya input pada teknik konvensional sehingga menekan perolehan pendapatan usahatani.

Selain mengetahui kelayakan suatu usahatani dijalankan, perlu diperhitungkan apakah korbanan yang dikeluarkan dalam proses produksi sudah efisien atau belum. Sebagaimana kasus yang terjadi pada penelitian ini, bila petani hanya mengejar 
hasil panen yang tinggi, namun korbanan yang dikeluarkan untuk setiap tambahan hasil panen cukup besar, maka penambahan input usahatani justru tidak efisien. Terbukti nilai R/CRatio pada teknik BJA justru lebih rendah dari nilai R/C-Ratio teknik konvensional. Hal ini terjadi karena peningkatan hasil panen atau penerimaan usahatani sebesar 57,6\% lebih rendah dari peningkatan biaya input yang mencapai $68,1 \%$.

Menurut Dominic Salvatore (1997), persentase tambahan biaya input yang melebihi persentase tambahan penerimaan merupakan bukti bahwa usahatani tidak efisien. Keuntungan yang akan dicapai tidak akan maksimal karena pemborosan penggunaan input.

Berdasarkan analisis $\mathrm{B} / \mathrm{C}$ ratio terlihat bahwa usahatani kedelai dengan teknik konvensional memiliki nilai $\mathrm{B} / \mathrm{C}$ ratio 0,27 yang berarti setiap $\mathrm{Rp}$. 1000,biaya yang dikeluarkan oleh petani Kedelai dengan teknik konvensional akan memperoleh keuntungan sebesar Rp. 270,-. Demikian Juga untuk usahatani kedelai dengan teknik BJA memiliki nilai $B / C$ ratio 0,19 yang berarti setiap Rp.1000,- biaya yang dikeluarkan oleh petani akan diperoleh keuntungan sebesar Rp. 190,-. Nilai B/C ratio pada teknik konvensional lebih tinggi dibandingkan nilai $\mathrm{B} / \mathrm{C}$ ratio pada teknik $\mathrm{BJA}$.
Kedua jenis usaha tani kedelai teknik konvensional maupun teknik BJA memiliki $\mathrm{B} / \mathrm{C}$ ratio $>0$,dapat diartikan jika usahatani kedelai dengan kedua teknik tersebut secara ekonomi layak untuk diusahakan atau dapat memberikan manfaat bagi petani.

\section{Kesimpulan}

1. Pendapatan petani pada budidaya kedelai yang menerapkan paket teknologi BJA Rp. 2.140.000 untuk satu kali musim tanam, lebih tinggi dari pendapatan yang diperoleh dari budidaya konvensional Rp1.810.000 untuk satu kali musim tanam.

2. Nilai $R / C$-Ratio pada budidaya BJA $(1,2)$ lebih kecil dibanding nilai $R / C$ Ratio pada budidaya kedelai konvensional $(1,3)$.

\section{Saran}

1. Sebaiknya program yang ditawarkan kepada petani dengan biaya produksi yang rendah sehingga petani dapat menerapkan teknologi BJA secara swadaya dan berkesinambungan

2. Jika petani akan melanjutkan untuk berusahatani kedelai hitam, maka perlu adanya peran dari pemerintah atau lembaga yang terkait didalamnya untuk menjamin ketersediaan pasar. 


\section{DAFTAR PUSTAKA}

Adisarwanto. 2005. Kedelai. Penebar Swadaya. Jakarta.

Badan Pusat Statistik Provinsi Jambi. 2007. Provinsi Jambi Dalam Angka 2007. Jambi.

Badan Pusat Statistik Provinsi Jambi. 2008. Provinsi Jambi Dalam Angka 2008. Jambi.

Badan Pusat Statistik Provinsi Jambi. 2009. Provinsi Jambi Dalam Angka 2009. Jambi.

Badan Pusat Statistik Provinsi Jambi. 2010. Provinsi Jambi Dalam Angka 2010. Jambi.

Badan Pusat Statistik Provinsi Jambi. 2011. Provinsi Jambi Dalam Angka 2011 Jambi.

Badan Pusat Statistik Provinsi Jambi. 2012. Provinsi Jambi Dalam Angka 2012. Jambi.

Badan Pusat Statistik Provinsi Jambi. 2013. Provinsi Jambi Dalam Angka 2013. Jambi.

Badan Pusat Statistik Provinsi Jambi. 2014. Provinsi Jambi Dalam Angka 2014. Jambi.

Badan Pusat Statistik Provinsi Jambi. 2015. Provinsi Jambi Dalam Angka 2015. Jambi.
Badan Pusat Statistik Provinsi Jambi. 2016. Provinsi Jambi Dalam Angka 2016. Jambi.

Direktorat Jenderal Tanaman Pangan. 2015. Petunjuk Teknis Pengelolaan Produksi Kedelai.

Dominic Salvatore.1997. Ekonomi Internasional. Alih bahasa Drs. Haris Munandar. Edisi Kelima, Jakarta: PT. Erlangga.

Hernanto, F. 2001. IImu Usahatani. Penebar Swadaya. Jakarta.

Kasmir dan Jakfar, 2007. Studi Kelayakan Bisnis Edisi-2. Jakarta: Kencana Prenada Media Group

Krisnamurthi, B. 2001. Agribisnis. Yayasan Pengembangan Sinar Tani. Jurusan Ilmu-IImu Sosial Ekonomi Pertanian. Fakultas Pertanian. IPB, Bogor.

Rahim, A dan Hastuti, Retno Dwi 2008. Pengantar, Teori dan Kasus Ekonomika Pertanian. Penebar Swadaya. Jakarta.

Soekartawi. 2002. Prinsip Dasar Ekonomi Pertanian: Teori dan Aplikasi. PT Raja Grafindo Persada. Jakarta.

Soekartawi.1995. Analisis Usahatani. Penerbit Universitas Indonesia. Jakarta. 